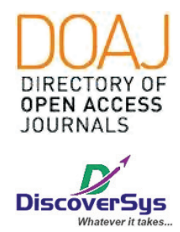

Published by DiscoverSys

\section{Karakteristik korban kekerasan seksual pada anak yang ditangani di Unit PPA Satreskrim Polresta Denpasar pada tahun 2015-2016}

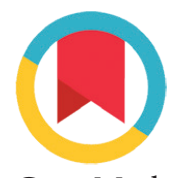

CrossMark

\author{
Ary Priadnyana, ${ }^{1 *}$ Ida Bagus Putu Alit, ${ }^{2}$ Dudut Rustyadi ${ }^{3}$
}

\title{
ABSTRACT
}

Background: Child Sexual Abuse is defined as the act of forcing or causing children to be involved in sexual activities that they cannot yet to fully comprehend and give consent because of their development which is still in the initial phase. Within the last three decades, child sexual abuse has drawn considerable attention and become a severe issue with the global prevalence rate estimated to be around $12 \%$.

Aim: This study was conducted to determine the proportion and characteristics of child sexual abuse victims handled and recorded by Women and Child Service of Criminal Investigational Unit in Denpasar City Police Station from January 2015 until December 2016.

Method: This study was designed as a descriptive cross-sectional that was conducted in Women and Child Service of Criminal Investigational Unit in Denpasar Police Station. All data were obtained from secondary data which is the Police Investigation Report (BAP) of all child abuses during the year 2015-2016.
Result: The results from this study show that from 92 child abuse victims, the proportion of child sexual abuse victims are the most frequent with 52 people (56.5\%). From 52 victims of child sexual abuse, the most frequent age group is the age group that lies within the range of $13-18$ years old, which compromises 30 people (57.7\%). The most common gender is female with 49 people (94.2\%). The most frequently found family structure is an intact family structure with 50 people (96.2\%). In the history of domestic violence in the family, the majority of the children had their police investigation report with a history of domestic violence in the family as many as 32 people (61.5\%). The number of children with no history of domestic violence in the family exceeded that of the ones with a history of domestic violence in the family which comprises of 14 people (26.9\%). The educational status of their head of the family was found to be high about 52 people (100\%). Conclusion: The number of child abuses during the year 2015-2016 which is handled by Denpasar Police Station team is the most frequent report than any child traumatic incidence about $56.5 \%$.

Keywords: Sexual Abuse, Child, Characteristics of Victims

Cite This Article: Priadnyana, A., Alit, I.B.P., Rustyadi, D. 2020. Karakteristik korban kekerasan seksual pada anak yang ditangani di Unit PPA Satreskrim Polresta Denpasar pada tahun 2015-2016. Intisari Sains Medis 11(2): 884-891. D0I: 10.15562/ism.v11i2.204

\section{ABSTRAK}

Kekerasan seksual pada anak didefinisikan sebagai tindakan yang memaksa atau menyebabkan anak terlibat dalam aktivitas seksual yang belum bisa sepenuhnya mereka pahami dan beri persetujuan, karena perkembangan mereka yang masih pada tahap awal. Dalam tiga dekade terakhir, kasus kekerasan seksula pada anak telah menjadi perhatian yang besar dan permasalahan yang cukup serius dengan angka prevalensi dunia sekitar $12 \%$.

Tujuan: Penelitian ini dilaksanakan untuk mengetahui proporsi dan karakteristik korban kekerasan seksual pada anak yang ditangani dan tercatat di Unit Pelayanan Perempuan dan Anak Satuan Reserse Kriminal Polresta Denpasar (Unit PPA Satreskrim Polresta Denpasar) pada periode Januari 2015 sampai Desember 2016.

Metode: Penelitian ini merupakan penelitian deskriptif cross sectional yang dilakukan di Unit PPA Satreskrim Polresta Denpasar. Data yang diperoleh berupa data sekunder berkas Berita Acara Pemeriksaan (BAP) korban kekerasan pada anak tahun 2015-2016.

Hasil: Hasil dari penelitian menunjukan dari 92 korban kekerasan pada anak, proporsi korban kekerasan seksual pada anak adalah yang terbanyak sejumlah 52 orang (56,5\%). Dari 52 korban kekerasan seksual pada anak, kelompok umur terbanyak adalah korban pada rentang umur 13 - 18 tahun sejumlah 30 orang $(57,7 \%)$. Jenis kelamin terbanyak yaitu perempuan sejumlah 49 orang (9,2\%). Keutuhan keluarga terbanyak adalah keutuhan keluarga yang utuh sejumlah 50 orang (96,2\%). Pada riwayat adanya kekerasan dalam rumah tangga di keluarga, sebagian besar korban memiliki berkas BAP yang tidak mencantumkan/tidak tersedianya riwayat adanya kekerasan dalam rumah tangga di keluarga sejumlah 32 orang $(61,5 \%)$ sedangkan pada yang riwayatnya tersedia, jumlah anak dengan keluarga tanpa riwayat adanya kekerasan dalam rumah tangga lebih banyak dari yang ada yaitu sejumlah 14 orang (26,9\%). Seluruh tingkat pendidikan kepala keluarga anak ditemukan tinggi sejumlah 52 orang (100\%).

Simpulan: Jumlah kekerasan seksual pada anak yang ditangani di Unit PPA Satreskrim Polresta Denpasar tahun 2015-2016 lebih tinggi dari bentuk kekerasan lainnya, yaitu 56.5\% dari seluruh (keempat) jenis kekerasan pada anak.
Disetujui: $15-06-2018$

Diterbitkan: 01-08-2020 
Kata Kunci: Kekerasan Seksual, Anak, Karakteristik Korban

Cite Pasal Ini: Priadnyana, A., Alit, I.B.P., Rustyadi, D. 2020. Karakteristik korban kekerasan seksual pada anak yang ditangani di Unit PPA Satreskrim Polresta Denpasar pada tahun 2015-2016. Intisari Sains Medis 11(2): 884-891. D0I: 10.15562/ism.v11i2.204

\section{PENDAHULUAN}

Kekerasan seksual terhadap anak atau child sexual abuse adalah salah satu dari 4 jenis kekerasan pada anak secara umum, selain 3 jenis kekerasan lainnya yaitu penelantaran, kekerasan fisik, dan kekerasan psikis. Meskipun tergolong jenis kekerasan yang baru sering dilaporkan belakangan ini jika dibandingkan kekerasan lainnya, kekerasan seksual pada anak tetap tidak bisa diabaikan karena angkanya yang terus mengalami peningkatan dan dampak yang ditanggung oleh anak-anak tersebut yang dapat mereka bawa sampai masa dewasa. ${ }^{1,2}$

Saat ini kasus kekerasan seksual pada anakanak telah menjadi permasalahan masyarakat secara global. Padahal, sebelum 3 dekade yang lalu, kasus ini masih dianggap kasus yang sangat jarang dilaporkan. ${ }^{1}$ Namun, belakangan ini penelitian menunjukan bahwa kekerasan seksual pada anak terus meningkat dan dapat menyebabkan beberapa dampak buruk bagi anak dalam hidupnya selama bertahun-tahun. ${ }^{3}$ Ini berarti permasalahan ini perlu ditangani dengan segera.

Walaupun permasalahan ini dianggap baru menjadi perhatian di dunia, namun kasus kekerasan seksual pada anak sudah cukup meresahkan. ${ }^{4}$ Kasus ini telah dianggap sebagai kasus yang lebih sering dari jumlah kasus diabetes, kanker dan penyakit jantung kongenital pada anak-anak. Menurut lebih dari 300 penelitian, angka prevalensi kekerasan seksual pada anak secara global mencapai sekitar $12 \% .{ }^{5}$ Pada tahun 2011 , sebuah sistem data menunjukan bahwa jumlah anak yang dirujuk ke pusat perlindungan anak mencapai angka sekitar 3 juta anak, dan 9\% diantaranya mengalami kekerasan seksual. Menurut sebuah literatur, kasus kekerasan seksual pada anak paling banyak terjadi pada anak berusia 12-14 tahun. ${ }^{1}$

Beberapa literatur dan penelitian juga menyebutkan bahwa laporan kasus kekerasan seksual pada anak tersebut tidak menunjukan gambaran secara keseluruhan. Hal ini karena jumlah kasus yang tidak pernah ditangani maupun dilaporkan masih cukup banyak. Kasus kekerasan seksual pada anak yang tidak ditangani tepat waktu juga mempersulit pembuktiannya karena tanda-tanda luka setelah terjadinya kekerasan dapat hilang. ${ }^{5,6}$

Terdapat variasi mengenai proporsi anak yang mengalami kekerasan seksual dibandingkan dengan seluruh jenis kekerasan pada anak di berbagai negara. ${ }^{7}$ Di Kota Denpasar, sebagian besar kekerasan seksual pada anak ditangani secara hukum di Unit Pelayanan Perempuan dan Anak Satuan Reserse Kriminal Polresta Denpasar atau Unit PPA Satreskrim Polresta Denpasar, dan data mengenai kasus-kasus tersebut tercatat dalam suatu berkas yang disebut berkas Berita Acara Pemeriksaan (BAP).

Penelitian ini dilakukan untuk mengetahui proporsi kekerasan seksual pada anak dibandingkan jumlah seluruh bentuk kekerasan pada anak (keempat jenis kekerasan pada anak secara umum) yang ditangani di Unit PPA Satreksrim Polresta Denpasar tahun 2015-2016, dan karakteristik korban kekerasan seksual yang dapat menjadi faktor terjadinya kekerasan seksual pada anak, sehingga dapat diketahui karakteristik yang dominan terdapat pada anak yang mengalami kekerasan seksual.

\section{METODE}

Penelitian ini merupakan penelitian deskriptif cross-sectional. Lokasi penelitian ini bertempat di Unit PPA Satreskrim Polresta Denpasar dan dilaksanakan dari Mei 2017 hingga September 2017. Kriteria inklusi sampel penelitian ini adalah seluruh anak-anak dibawah usia 18 tahun yang mengalami keempat jenis kekerasan dan tercatat di Unit PPA Satreskrim Polresta Kota Denpasar dari Januari 2015 hingga Desember 2016. Sampel juga tidak memenuhi kriteria eksklusi, yaitu sudah menikah sebelum berusia 18 tahun, sehingga berkemungkinan tidak lagi tinggal bersama orang tua.

Besar sampel ditentukan dengan menggunakan teknik total sampling. Jumlah sampel minimum dihitung dengan rumus besar sampel untuk data nominal pada proporsi tunggal, yaitu dengan nilai $\mathrm{P}=0,1014$, nilai $\mathrm{Q}=1-\mathrm{P}=0,8896$, kemudian besar $\mathrm{Za}=1,96$. Dari ketentuan tersebut, didapatkan jumlah sampel minimal yang diperlukan adalah sebanyak 35 sampel minimal. ${ }^{2}$ Terdapat 6 variabel yang diteliti pada penelitian ini, yaitu korban kekerasan seksual pada anak, umur, jenis kelamin, keutuhan keluarga, riwayat kekerasan dalam rumah tangga di keluarga, serta tingkat pendidikan keluarga, yang dilihat dari jenjang pendidikan terakhir kepala keluarga korban. Data yang telah terkumpul dianalisis dengan program analisis komputer, dimana analisis dilakukan secara univariat untuk mengetahui distribusi frekuensi dari variabel penelitian. Data kemudian disajikan dalam bentuk tabel. 


\section{HASIL PENELITIAN}

Penelitian ini dilaksanakan dengan melihat data anak-anak di bawah 18 tahun yang mengalami keempat jenis kekerasan (seksual, fisik, psikis, dan penelantaran) dan ditangani di Unit PPA Satreskrim Polresta Denpasar pada periode Januari 2015 sampai Desember 2016. Sampel penelitian menggunakan total sampling dan dari 92 kasus kekerasan pada anak ditemukan pada berkas BAP Polresta Denpasar, didapatkan bahwa 52 kasus adalah kasus kekerasan seksual dan sisanya adalah kasus kekerasan selain seksual (kekerasan fisik, kekerasan psikis, dan penelantaran).

\section{a. Proporsi Kekerasan Seksual dibandingkan seluruh Kekerasan pada Anak yang ditangani di Unit PPA Satreskrim Polresta Denpasar Tahun 2015-2016.}

Tabel 1 merupakan distribusi frekeuensi proporsi korban kekerasan seksual pada anak-anak yang ditangani oleh Unit PPA Satreskrim Polresta Denapsar pada tahun 2015-2016 dibandingkan jenis kekerasan lainnya.

Pada tabel 1, terlihat dari 92 kasus kekerasan pada anak dapat diketahui bahwa proporsi kasus kekerasan seksual pada anak lebih tinggi (52 kasus) dibandingkan kasus kekerasan lainnya (selain seksual) pada anak dengan rasio perbandingan 1.4:1.

Tabel 1 Distribusi Frekuensi Proporsi Kekerasan pada Anak

\begin{tabular}{lcc}
\hline Proporsi Kekerasan pada Anak & Jumlah & Persentase (\%) \\
\hline Kekerasan seksual & 52 & $56,5 \%$ \\
Kekerasan selain seksual & 40 & $43,5 \%$ \\
Total & 92 & $100 \%$ \\
\hline
\end{tabular}

Tabel 2 Distribusi frekuensi korban kekerasan seksual pada anak berdasarkan kelompok umur

\begin{tabular}{lcc}
\hline Karakteristik kelompok umur & Jumlah & Persentase (\%) \\
\hline 0-8 tahun & 15 & $28,8 \%$ \\
9-12 tahun & 7 & $13,5 \%$ \\
13-18 tahun & 30 & $57,7 \%$ \\
Total & 52 & $100 \%$ \\
\hline
\end{tabular}

Tabel 3 Distribusi frekuensi korban kekerasan seksual pada anak berdasarkan jenis kelamin

\begin{tabular}{lcc}
\hline Karakteristik jenis kelamin & Jumlah & Persentase (\%) \\
\hline Laki-laki & 3 & $5,77 \%$ \\
Perempuan & 49 & $9,42 \%$ \\
Total & 52 & $100 \%$ \\
\hline
\end{tabular}

\section{b. Gambaran Populasi Studi Berdasarkan Kelompok Umur pada Kasus Kekerasan Seksual Anak.}

Karakteristik kelompok umur korban kekerasan seksual pada anak di bawah 18 tahun yang ditangani oleh Unit PPA Satreskrim Polresta Denpasar pada tahun 2015-2016 dibagi menjadi 3 kategori menurut pembagian oleh Finkelhor (1979), yaitu anak-anak (0-8 tahun), prepubertas (9-12 tahun), serta remaja pubertas (13-18 tahun). ${ }^{8}$

Pada tabel 2, terlihat bahwa mayoritas korban berada pada kelompok umur 13-18 tahun, kemudian diikuti dengan kelompok umur 0-8 tahun, dan proporsi terendah adalah korban dengan kelompok umur 9-12 tahun.

\section{c. Gambaran Populasi Studi Berdasarkan Jenis Kelamin pada Kasus Kekerasan Seksual Anak.}

Karakteristik jenis kelamin korban kekerasan seksual pada anak yang ditangani di Unit PPA Satreskrim Polresta Denapsar pada tahun 20152016 dibagi menjadi laki-laki dan perempuan.

Pada tabel 3, terlihat bahwa korban kekerasan seksual pada anak yang ditangani oleh Unit PPA Satreskrim Polresta Denapsar pada tahun 20152016 didominasi oleh perempuan dengan rasio perbandingan perempuan dan laki-laki adalah sebesar 16.3: 1 .

\section{d. Gambaran Populasi Studi Berdasarkan Keutuhan Keluarga pada Kasus Kekerasan Seksual Anak.}

Karakteristik keutuhan keluarga korban kekerasan seksual pada anak yang ditangani oleh Unit PPA Satreskrim Polresta Denapsar pada tahun 20152016 dibagi menjadi 2 kategori, yaitu utuh dan tidak utuh, yang dilihat dari apakah kedua orang tua kandung di keluarga lengkap atau tidak.

Pada kasus kekerasan seksual pada anak, jumlah korban yang memiliki keutuhan keluarga yang utuh terlihat lebih dominan dibandingkan korban yang tinggal dengan keluarga yang tidak utuh dengan rasio yaitu 25:1.

\section{e. Gambaran Populasi Studi Berdasarkan Riwayat Adanya Kekerasan Dalam Rumah Tangga di Keluarga pada Kasus Kekerasan Seksual Anak.}

Berikut ini adalah tabel distribusi frekuensi korban kekerasan seksual pada anak yang ditangani oleh Unit PPA Satreskrim Polresta Denapsar pada tahun 2015-2016 berdasarkan riwayat adanya kekerasan dalam rumah tangga di keluarga anak yang tercatat saat mewawancarai anak, keluarga anak, maupun orang yang mengantar anak ke Unit PPA Satreskrim Polresta Denpasar. 
Tabel 4 Distribusi korban kekerasan seksual pada anak berdasarkan keutuhan keluarga

\begin{tabular}{lcc}
\hline Karakteristik keutuhan keluarga & Jumlah & Persentase (\%) \\
\hline Utuh (tinggal dengan kedua orang tua kandung) & 50 & $96,2 \%$ \\
Tidak utuh (selain dengan kedua orang tua kandung) & 2 & $3,8 \%$ \\
Total & 52 & $100 \%$ \\
\hline
\end{tabular}

Tabel 5 Distribusi korban kekerasan seksual pada anak Berdasarkan Riwayat Adanya Kekerasan Dalam Rumah Tangga di Keluarga

Karakteristik riwayat adanya kekerasan dalam rumah tangga di keluarga

\begin{tabular}{cc} 
Jumlah (N) & Persentase (\%) \\
\hline 6 & $11,5 \%$ \\
14 & $26,9 \%$ \\
32 & $61,5 \%$ \\
52 & $100 \%$
\end{tabular}

\begin{tabular}{lcc} 
Tabel 6 & $\begin{array}{l}\text { Distribusi Frekuensi Korban Kekerasan Seksual pada Anak Berdasarkan } \\
\text { Karakteristik Tingkat Pendidikan Keluarga }\end{array}$ \\
\hline Karakteristik tingkat pendidikan & Jumlah & Persentase (\%) \\
\hline Tinggi (Tamat SMA) & 52 & $100 \%$ \\
Rendah (Tidak tamat SMA) & 0 & $0 \%$ \\
Total & 52 & $100 \%$ \\
\hline
\end{tabular}

Sebagian besar korban kekerasan seksual pada anak memiliki catatan berkas BAP dimana riwayat adanya kekerasan dalam rumah tangga pada keluarga tidak tersedia atau tidak ditanyakan saat wawancara dengan korban (sebanyak 32 data tidak tersedia), sedangkan pada korban dimana riwayat kekerasan dalam rumah tangga di keluarga tercatat di BAP, jumlah korban dengan adanya kekerasan dalam rumah tangga di keluarga terlihat lebih sedikit dibandingkan korban dengan keluarga yang tidak memiliki riwayat kekerasan dalam rumah tangga berdasarkan catatan BAP.

\section{f. Gambaran Populasi Studi Berdasarkan Tingkat Pendidikan Keluarga pada Kasus Kekerasan Seksual Anak}

Karakteristik tingkat pendidikan keluarga korban kekerasan seksual pada anak yang ditangani oleh Unit PPA Satreskrim Polresta Denapsar pada tahun 2015-2016 dibagi menjadi 2 kategori menurut pembagian tingkat pendidikan oleh Arikunto (2008), yaitu tingkat pendidikan rendah jika tidak tamat SMA sederajat, dan tinggi jika telah tamat SMA sederajat. Tingkat pendidikan keluarga dilihat dari jenjang pendidikan terakhir kepala keluarga korban.

Pada karakteristik tingkat pendidikan keluarga, peneliti menemukan bahwa seluruh kasus kekerasan seksual pada anak yang diteliti memiliki tingkat pendidikan keluarga yang tinggi (tamat
SMA), yang dilihat dari tingkat pendidikan kepala keluarga.

\section{DISKUSI}

Pada penelitian ini dilakukan analisis terhadap korban kekerasan pada anak yang tercatat di Unit PPA Satreskrim Polresta Denpasar pada tahun 2015-2016, ditemukan bahwa kekerasan seksual pada anak lebih banyak terjadi dibandingkan dengan kekerasan selain seksual pada anak. Hasil ini berbeda dari data-data sebelumnya. Data registrasi keamanan keluarga nasional Saudi Arabia (Saudi Arabian National Family Safety Registry) yang dikutip di dalam literatur oleh Al-Shail et al (2012), mendapatkan hasil yang berbeda pada proporsi kasus kekerasan seksual (22\%) dibandingkan dengan seluruh jenis kekerasan. ${ }^{9}$ Departemen Pelayanan dan Kesehatan Amerika Serikat (2006) yang memperoleh data dari Pelayanan dan Perlindungan Anak atau Child Protection Service juga menyebutkan presentase yang berbeda pada kasus kekerasan seksual $(8,8 \%)$, dan lebih banyak pada kasus kekerasan selain seksual (86,7\%). ${ }^{10}$ Lamont (2011) menjelaskan bahwa berdasarkan data yang dikumpulkan oleh Australian Institute Human and Welfare, persentase kekerasan seksual pada anak adalah $12.7 \%$ dibandingkan dengan seluruh (keempat) jenis kekerasan terhadap anak. ${ }^{11}$ 
Perbedaan hasil peneliti dengan data-data nasional beberapa negara di atas mungkin disebabkan karena beberapa hal. Pertama, perbedaan jumlah sampel peneliti yang berbeda dari data-data tersebut. Kedua, peneliti hanya melakukan pengambilan kasus kekerasan yang telah dilaporkan di Unit PPA Satreskrim Polresta Denpasar, sedangkan datasebelumnya didapat dari data nasional yang ada. Ketiga, pada penelitian lain ditemukan dan dicatat bahwa seorang anak dapat mengalami lebih dari satu jenis kekerasan, sedangkan berkas BAP Polresta Denpasar hanya mencantumkan satu kekerasan utama yang membuat seseorang anak dilaporkan ke Unit PPA Satreskrim Polresta Denpasar, sehingga perbandingan antar jenis kekerasan tentu berbeda. Kekerasan psikis adalah kekerasan yang sangat jarang dilaporkan ke Unit PPA Satreskrim Polresta Denpasar, begitu juga dengan kasus penelantaran dimana pada kasus litigasi yang ada di kepolisian, pembuktiannya kasusnya lebih sulit. Sedangkan data-data sebelumnya kemungkinan juga diambil dari data non-litigasi selain di kepolisian sehingga data yang terdeteksi pada kasus non litigasi munkgin saja tidak/belum terdeteksi pada kasus litigasi. Hal yang sama juga berlaku untuk kasus kekerasan fisik, dimana biasanya hanya kasus yang berakibat fatal yang dilaporkan ke kepolisian dan menjadi kasus litigasi.

Berdasarkan karakteristik umur korban, penelitian ini sejalan dengan penelitian yang dilaksanakan oleh Mckillop et al (2015) yang mendapatkan proporsi terbanyak pada korban dengan kelompok umur yang serupa yaitu diatas 12 tahun (47\%). ${ }^{12}$ Penelitian yang dilaksanakan oleh Finkelhor et al (2008) juga menemukan korban didominasi oleh kelompok umur yang serupa, yaitu tertinggi pada rentang umur $15-17$ tahun (54\%). ${ }^{13}$ Karayianni et al (2017) mendapatkan hasil bahwa korban dengan proporsi tertinggi pada rentang umur yang sedikit berbeda yaitu 12-16 tahun (28\%). ${ }^{7}$ Variasi persentase diatas mungkin karena perbedaan pengelompokan rentang umur pada tiap peneliti.

Namun, hasil ini bertentangan dari beberapa teori di literatur. Menurut Finkelhor et al (1979), berlawanan dari hasil peneliti, kekerasan seksual justru disebutkan rentan saat anak-anak berada pada masa prapubertas (9-12 tahun). Alasannya adalah walaupun mereka mulai mengerti pengertian seksualitas orang dewasa, kemampuan mereka untuk memproteksi diri dan menghindari ancaman seksual orang dewasa belum sebaik remaja yang lebih tua (pada usia 13-18 tahun). ${ }^{14}$

Perbedaan ini mungkin karena pada anak dengan usia yang lebih muda, pelaporan ke pihak yang berwenang (kepolisian) cenderung tertunda, sedangkan Finkelhor et al menyimpulkan dari beberapa penelitian yang hasilnya tidak hanya dari laporan kepolisian dan data sekunder, melainkan survey secara langsung. Pada kasus litigasi yang berada di kepolisian, biasanya anak dengan usia yang semakin tua lebih bisa mengeluhkan ke orang tua mengenai kekerasan seksual yang dialaminya, sehingga pelaporan kasus tersebut ke kepolisian bisa lebih segera dilaporkan dan pembuktiannya lebih mudah. Menurut Waterhouse dan Townsend, anak yang lebih muda cenderung melaporkan pengalaman kekerasan seksual saat mereka lebih dewasa, walaupun jauh sebelum itu sudah mengalami kekerasan seksual. ${ }^{15,16} \mathrm{Hal}$ ini diduga karena saat lebih dewasa, anak lebih memiliki pemikiran yang matang untuk mengungkapkan pengalaman kekerasan seksual tersebut. ${ }^{16}$

Korban kekerasan seksual pada anak yang ditangani di Unit PPA Satreskrim Polresta Denpasar didominasi oleh anak perempuan (94.2\%). Hasil penelitian ini sesuai dengan beberapa penelitian lainnya yang mendapatkan bahwa perempuan lebih banyak menjadi korban kekerasan seksual, seperti penelitian yang dilaksanakan oleh PerezFuentes et al (2013) dengan 75,2\% korban adalah anak perempuan, Akani et al (2015) yaitu 98\% korban adalah anak perempuan, dan Finkelhor (2008) menemukan 89\% korban adalah anak perempuan. ${ }^{2,3,13}$

Hasil penelitian ini sesuai dengan teori di literatur. Menurut Pérez-Fuentes et al (2013), jenis kelamin perempuan konsisten secara global menjadi karakteristik korban kekerasan seksual dibandingkan laki-laki karena laki-laki secara umum dan kultural dianggap sebagai pihak yang memegang kekuasaan serta menginisiasi aktivitas seksual, sedangkan perempuan dalam berbagai kultur dianggap sebagai pihak yang diharapkan patuh terhadap laki-laki, sehingga lebih rentan mengalami kekerasan seksual. ${ }^{2}$ Wekerle \& Black (2017) menyebutkan laki-laki lebih jarang mengungkapkan pengalaman kekerasan seksual karena rasa takut akan stigma di masyarakat akan berkurangnya maskulinitas. ${ }^{17}$

Pada karakteristik keutuhuan keluarga, penelitian ini menunjukan bahwa sebagian besar korban kekerasan seksual pada anak yang ditangani di Unit PPA Satreskrim Polresta Denpasar pada tahun 2015-2016 tinggal dengan keluarga yang utuh. Hasil ini sesuai dengan penelitian yang dilaksanakan oleh Canton-Cortez et al (2014) dimana didapatkan bahwa jumlah korban yang tinggal dengan keutuhan keluarga yang utuh lebih dominan (79.8\%) jika dibandingkan dengan korban yang tinggal dengan keluarga yang tidak utuh (20.2\%). ${ }^{18}$ Murnane \& Peachey (1997) mendapatkan hasil yang berbeda pada penelitian mereka dimana korban yang 
tinggal dengan keluarga yang tidak utuh lebih dominan (59\%). ${ }^{19}$ Selanjutnya, penelitian yang dilaksanakan oleh Mitchell et al (2005) mendapatkan hasil yang berbeda pula dimana jumlah korban yang tinggal dengan keluarga yang tidak utuh lebih tinggi $(64 \%) .^{20}$

Perbedaan hasil ini dengan beberapa penelitian terakhir di atas mungkin karena beberapa hal. Pertama, perbedaan besar sampel penelitian ini dengan penelitian-penelitian sebelumnya. Kemudian, pada kasus kekerasan seksual pada anak yang ditangani di Polresta Denpasar, sebagian besar kasus adalah ekstrafamilial dimana pelakunya bukan orang tua, sehingga kasus tersebut dilaporkan oleh keluarga anak yang cenderung memiliki keutuhan keluarga utuh/baik-baik saja. Kasus kekerasan seksual pada keutuhan keluarga yang tidak utuh biasanya dilakukan oleh orang di rumah korban seperti ayah tiri, kekasih ibu, sehingga sebagai pelaku, orang tersebut tidak akan melaporkan kasus tersebut pada pihak yang berwajib. Jadi, kasus kekerasan seksual pada anak yang memiliki keutuhan keluarga yang tidak utuh mungkin lebih banyak dijumpai pada kasus non litigasi seperti pada penelitian yang dilakukan oleh Mitchell et al (2005). ${ }^{20}$ Selain itu, keluarga yang utuh cenderung memberi perhatian yang lebih baik pada anak-anaknya sehingga saat adanya kasus kekerasan seksual terhadap anak, maka pelaporan kepada pihak kepolisian dapat segera dilaksanakan.

Hasil ini juga berbeda dengan teori di literatur. Menurut literatur, tidak utuhnya keutuhan keluarga menjadi karakteristik dan juga faktor risiko pada sejumlah korban yang dilaporkan di beberapa penelitian. Laaksonen et al (2011) menyebutkan bahwa tidak adanya ayah kandung akan meningkatkan paparan anak perempuan terhadap laki-laki asing dari luar yang tidak sedarah (terutama ayah tiri dan kekasih ibu selain ayah kandung) sehingga lebih meningkatkan kerentanan mengalami tindak kekerasan seksual. Ayah kandung juga memiliki peran sebagai pengendali perilaku berisiko anak yang meningkatkan risiko kekerasan seksual. ${ }^{21}$ Ketiadaan ibu kandung dianggap meningkatkan kerentanan anak terutama anak perempuan untuk menjadi korban yang diduga karena berkurangnya pengawasan terutama saat adanya kehadiran ayah tiri di rumah, dan hal ini dapat meningkatkan kemungkinan incest. ${ }^{22,23}$

Berdasarkan riwayat adanya kekerasan dalam rumah tangga di keluarga, mayoritas korban kekerasan seksual pada anak yang diteliti di Unit PPA Satreskrim Polresta Denpasar memiliki berkas BAP yang tidak mencatumkan/tidak tersedianya riwayat kekerasan dalam rumah tangga di keluarga, sedangkan pada korban yang diketahui riwayat kekerasan dalam rumah tangga di keluarga, terlihat bahwa korban dengan keluarga dimana terdapat kekerasan dalam rumah tangga lebih sedikit $(11,5 \%)$ dibandingkan dengan yang tidak $(26,9 \%)$. Hasil ini bertentangan dengan beberapa penelitian lainnya yang menemukan bahwa adanya kekerasan dalam rumah tangga dominan terjadi pada keluarga korban kekerasan seksual pada anak, yaitu sebanyak 58\% dari seluruh kasus pada penelitian yang dilaksanakan oleh Cohen et al (2004), dan $71 \%$ dari seluruh kasus pada penelitian yang dilaksanakan oleh Hume (1997). ${ }^{24,25}$

Perbedaan hasil ini dapat disebabkan oleh beberapa hal. Pertama, cukup banyak sampel pada penelitian ini dimana data mengenai riwayat kekerasan dalam rumah tangga di keluarga tidak tersedia di BAP, sehingga tidak bisa menarik kesimpulan secara pasti apakah kekerasan dalam rumah tangga di keluarga dominan terjadi pada keluarga korban. Perbedaan jumlah sampel juga dapat menyebabkan perbedaan hasil. Kemudian, pada penelitian yang dilaksanakan oleh Cohen et al (2004), data didapatkan melalui sesi wawancara dan psikoterapi langsung pada korban, sehingga memungkinkan untuk mendapatkan data yang lebih detail, sedangkan peneliti hanya menggunakan berkas BAP untuk mencari data mengenai riwayat adanya kekerasan dalam rumah tangga di keluarga. ${ }^{24}$ Selain itu, seperti pada varibel keutuhan keluarga, anak dengan keluarga tanpa kekerasan dalam rumah tangga di keluarga cenderung mendapatkan perhatian yang lebih baik sehingga saat adanya kasus kekerasan seksual pada anak maka akan segera dilaporkan.

Hasil ini juga bertentangan dengan literatur. Anak yang terpapar akan kekerasan dalam rumah tangga di keluarga (kekerasan antar-pasangan) berkemungkinan menjadi korban kekerasan itu sendiri, termasuk kekerasan seksual. Devries et al (2017) menyebutkan bahwa adanya kekerasan dalam rumah tangga di keluarga meningkatkan kemungkinan anak mendapat kekerasan seksual baik secara intrafamilial maupun ekstrafamilial. Secara intrafamilial, disebutkan bahwa saat adanya kekerasan oleh pengasuh terhadap anak (termasuk kekerasan seksual), kemungkinan juga terjadi kekerasan antar pengasuh (terutama ayah kepada ibu). ${ }^{26}$ Hal ini sering terjadi karena menurut Ritchie et al (2002), terdapat karakteristik yang serupa antara pelaku incest dalam keluarga dengan pelaku kekerasan dalam rumah tangga (biasanya ayah terhadap ibu) dari segi taktik dan cara memanipulasi korbannya. ${ }^{27}$ Sehingga, seringkali saat adanya kekerasan seksual pada anak, juga terdapat kekerasan antar pasangan dalam keluarga (suatu konsep yang sering disebut co-occurence). 
Pada kekerasan seksual ekstrafamilial, adanya kekerasan dalam rumah tangga di dalam keluarga dapat mengurangi pengawasan orang tua pada anaknya dari lingkungan yang berisiko.

Seluruh kasus kekerasan seksual pada anak yang diteliti di Unit PPA Satreskrim Polresta Denpasar pada tahun 2015-2016 memiliki tingkat pendidikan yang tinggi yaitu tamat SMA. Penelitian yang dilaksanakan oleh Wonderlich (2000) menunjukan hal serupa, dimana ditemukan proporsi yang lebih besar pada anak dengan tingkat pendidikan keluarga yang tinggi (85\%). ${ }^{28}$ Beberapa penelitian lainnya mendapatkan hasil yang berbeda, dimana penelitian yang dilaksankan oleh Mekuria et al (2015) menemukan bahwa anak dengan tingkat pendidikan keluarga yang tinggi hanya sebanyak 6 dari seluruh kasus (15\%). ${ }^{29}$ Karayianni et al (2017) mendapatkan tingkat pendidikan ayah (sebagai kepala keluarga) pada kasus kekerasan seksual anak dominan rendah (57\%), dan sisanya berpendidikan tinggi. ${ }^{7}$

Perbedaan hasil peneliti dengan beberapa penelitian diatas kemungkinan karena kasus yang diteliti peneliti adalah kasus litigasi saja dimana orang-orang dengan pendidikan yang tinggi cenderung lebih mampu untuk mengenali kekerasan seksual serta mengerti pelaporannya ke pihak yang berwenang (seperti kepolisian), sehingga kasus kekerasan seksual pada anak yang keluarganya berpendidikan rendah mungkin tidak semuanya dilaporkan ke kepolisian. Perbedaan tempat dilaksanakannya penelitian juga dapat mengakibatkan perbedaan tingkat pendidikan penduduk setempat. Karayianni et al menentukan batas yang berbeda pada tingkat pendidikan, yaitu tingkat pendidikan rendah jika tidak mengenyam pendidikan universitas, sehingga presentase yang didapat berbeda dari hasil peneliti.

Hasil ini juga berbeda dengan teori di beberapa literatur. Beberapa literatur menyebutkan bahwa kasus kekerasan seksual pada anak dominan datang dari keluarga dengan tingkat pendidikan yang rendah. Menurut Mekuria et al (2015), saat tingkat pendidikan keluarga (yang diukur dari tingkat pendidikan kepala keluarga, yaitu Ayah) lebih tinggi, maka ayah akan lebih mampu untuk memberi perhatian pada anak (dalam hal ini, terutama anak perempuan) dan lebih mengerti mengenai kebutuhannya. Ayah yang memiliki pendidikan yang tinggi dapat mendiskusikan masalah seksual dengan anaknya dengan lebih mudah, sehingga memudahkan ayah memberi kemampuan untuk mengambil keputusan dan tindakan dalam menghindari pergerakan dari pelaku yang memungkinkan anak menjadi calon korban kekerasan seksual. ${ }^{30}$ Menurut Elbedour et al (2006), orang tua yang teredukasi dengan baik dapat mengaplikasikan program-program pencegahan yang ada pada anak-anaknya terhadap berbagai bentuk kekerasan. Selanjutnya, Bekele dan Deressa (2014) menyebutkan bahwa pendidikan ayah dapat memberikan pencegahan pada kekerasan seksual terhadap putrinya dengan melakukan komunikasi yang baik mengenai subjek yang berkaitan dengan seksual. ${ }^{31}$

\section{SIMPULAN}

Penelitian ini menunjukan bahwa jumlah kekerasan seksual pada anak yang ditangani di Unit PPA Satreskrim Polresta Denpasar tahun 2015-2016 lebih tinggi dari bentuk kekerasan lainnya, yaitu 56.5\% dari seluruh (keempat) jenis kekerasan pada anak. Dari segi sosio-demografi, mayoritas korban adalah anak perempuan, berada pada rentang umur 13- 18 tahun, dan seluruh korban memiliki keluarga berpendidikan tinggi, yaitu menyelesaikan pendidikan SMA sederajat.

Mayoritas korban memiliki keutuhan keluarga yang utuh, yaitu tinggal dengan kedua orang tua kandung. Sebagian besar korban memiliki catatan di berkas BAP dimana riwayat kekerasan dalam rumah tangga di keluarga tidak tersedia/tercantum. Pada korban dimana riwayat kekerasan dalam rumah tangga di keluarga tercantum di berkas BAP, sebagian besar keluarga korban tidak memiliki riwayat kekerasan dalam rumah tangga.

\section{DAFTAR PUSTAKA}

1. Negriff, S, Schneiderman J, Smith C, Schreyer J, \& Trickett P. Characterizing the sexual abuse experiences of young adolescents. Child Abuse \& Neglect. 2014; 38(2): 261-270.

2. Pérez-Fuentes G, Olfson M, Villegas L, Morcillo C, Wang S, Blanco C. Prevalence and correlates of child sexual abuse: a national study. Comprehensive Psychiatry. 2013; 54(1): 16-27.

3. Akani, M, Imasiku M, Paul R, Hazemba A. Characteristics of Child Sexual Abuse in Zambia. Medical Journal of Zambia. 2015; 42(4): 172.

4. Girgira T, Tilahun B, Bacha, T. Time to presentation, pattern and immediate health effects of alleged child sexual abuse at two tertiary hospitals in Addis Ababa, Ethiopia. BMC Public Health. 2014; 14(1): 2-6.

5. Hermann B, Banaschak S, Csorba R, Navratil F, Dettmeyer R Physical examination in child sexual abuse. Dtsch Arztebl Int. 2014; 111: 692-703.

6. Sedalk A, Mettenburg, J, Basena M, Petta, I, McPherson K, Greene A. Fourth National Incidence Study of Child Abuse and Neglect (NIS-4): Report to Congress. Washington D.C: U.S. Department of Health and Human Services, Administration for Children and Families; 2010.

7. Karayianni E, Fanti K, Diakidoy I, Hadjicharalambous M, Katsimicha E. Prevalence, contexts, and correlates of child sexual abuse in Cyprus. Child Abuse \& Neglect. 2017; 66: 41-52.

8. Sorenson SB, Geffner R, Lundberg-Love PK. Violence and Sexual Abuse at Home: Current Issues in Spousal Battering and Child Maltreatment. New York: Haworth Maltreatment and Trauma Press; 1997. 
9. Al-Shail, E., Hassan, A., Aldowaish, A. \& Kattan, H. The Cultural Reinforcers of Child Abuse. InTech. 2012; 26-29.

10. U.S Department of Health and Human Services. Child Maltreatment 2006. Washington D.C: United States Children's Bureau Administration for Children and Families; 2008.

11. Lamont A. Child abuse and neglect statistics. Melbourne: Australian Institute of Family Studies; 2011.

12. McKillop N, Brown S, Wortley R, Smallbone S. How victim age affects the context and timing of child sexual abuse: applying the routine activities approach to the first sexual abuse incident. Crime Science. 2015; 4(1): 3.

13. Finkelhor D, Hammer H, Sedlak A. Sexually assaulted children: National estimates \& characteristics. Juvenile Justice Bulletin. 2008; 2: 1-12.

14. Finkelhor D. Sexually Victimized Children. New York: Free Press; 1979.

15. Townsend C. Child Sexual Abuse Disclosure: What Practitioners Need to Know. Darkness to Light. 2016; 2: 11.

16. Waterhouse L. Child abuse and child abusers. London: Jessica Kingsley; 1996.

17. Wekerle C, Black T. Gendered violence: Advancing evidence-informed research, practice, and policy in addressing sex, gender, and child sexual abuse. Child Abuse \& Neglect. 2017; 66:166-170.

18. Cantón-Cortés D, Cortés M, Cantón, J. Child Sexual Abuse, Attachment Style, and Depression. Journal of Interpersonal Violence. 2014; 30(3): 420-436.

19. Murnane M, \& Peachey M. Clinical effects of sexual abuse of children: A Melbourne study. Australian Institute of Criminology. 1999; 2: 2-5.

20. Mitchell K, Finkelhor D, Wolak J. The Internet and Family and Acquaintance Sexual Abuse. Child Maltreatment. 2005; 10(1): 49-60.

21. Laaksonen T, Sariola H, Johansson A, dkk. Changes in the prevalence of child sexual abuse, its risk factors, and their associations as a function of age cohort in a Finnish population sample. Child abuse \& neglect. 2011; 35(7); 480-490.

22. Finkelhor D, Baron L. Risk Factors for Child Sexual Abuse. Journal of Interpersonal Violence. 1986; 1(1): 1.

23. Wilson RF. Trusting Mothers: A Critique of the American Law Institute's Treatment of De Facto Parents. Hofstra Law Review. 2010; 38: 1120-1122.
24. Cohen J, Deblinger E, Mannarino A, Steer R, Multisite A, Randomized Controlled Trial for Children With Sexual Abuse-Related PTSD Symptoms. Journal of the American Academy of Child \& Adolescent Psychiatry. 2004; 43(4): 393-402.

25. Hume M. The Relationship between Child Sexual Abuse, Domestic Violence And Separating Families. National Criminal Justice Reference Service. 2003: 1; 2-5.

26. Devries K, Knight L, Child J et al. Witnessing intimate partner violence and child maltreatment in Ugandan children: a cross-sectional survey. BMJ Open. 2017; 7(2): e013583.

27. Ritchie D, Bancroft R, Silverman, J. The Batterer As Parent: Addressing the Impact of Domestic Violence on Family Dynamics (SAGE Series on Violence Against Women). London: Sage Publications; 2012.

28. Wonderlich S, Crosby R, Mitchell J et al. Relationship of Childhood Sexual Abuse and Eating Disturbance in Children. Journal of the American Academy of Child \& Adolescent Psychiatry. 2000; 39(10): 1277-1283.

29. Mekuria A, Nigussie A, Abera M. Childhood sexual abuse experiences and its associated factors among adolescent female high school students in Arbaminch town, Gammo Goffa zone, Southern Ethiopia: a mixed method study. BMC International Health and Human Rights. 2015; 15(1): 8 .

30. Elbedour S, Abu-Bader S, Onwuegbuzie A, Abu-Rabia A, El-Aassam S. The scope of sexual, physical, and psychological abuse in a Bedouin-Arab community of female adolescents: The interplay of racism, urbanization, polygamy, family honor, and the social marginalization of women. Child Abuse \& Neglect. 2006; 30(3): 215-229.

31. Bekele T, Deressa W. Experience of Sexual Coercion and Associated Factors among Female Students of Ambo University in Ethiopia. Science Journal of Public Health. 2014; 2(6): 532 - 538 .

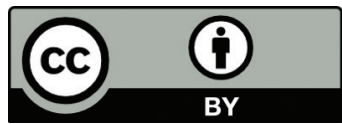

This work is licensed under a Creative Commons Attribution 